\title{
The recovery of some components of the renin angiotensin system in the rat pancreas after chronic exposure to hypoxic condition
}

\author{
S P Ip, T P Wong, S J Tsai ${ }^{1}$ and P S Leung \\ Department of Physiology, Faculty of Medicine, The Chinese University of Hong Kong, Shatin, New Territories, Hong Kong \\ ${ }^{1}$ Department of Physiology, National Cheng Kung University Medical College, Tainan, Taiwan \\ (Requests for offprints should be addressed to P S Leung; Email: psleung @ cuhk.edu.hk)
}

\begin{abstract}
Previous studies have shown that the expression of the major components from a local pancreatic renin-angiotensin system (RAS) was upregulated after chronic exposure to oxygen deprivation (10\% oxygen). In the present study, the reversibility of expression for the pancreatic RAS affected by chronic hypoxia was investigated in the pancreas. Rats were first subject to hypoxia for one month and they were then returned to normoxic conditions for a varying period of time (1, 2, 3 and 4 weeks). The degree of recovery in the expression of RAS components was analyzed with standard curve-quantitative competitive-reverse transcription-polymerase chain reaction (SC-QC-RT-PCR), Western blot analysis and a specific assay for angiotensin-converting enzyme (ACE) activity. Results from SC-QC-RT-PCR showed that the upregulated expression of angiotensin II type $1\left(\mathrm{AT}_{1}\right)$ receptor mRNA following chronic hypoxia could be completely restored to the control level after the rats were returned to the normoxic condition for 3 weeks. The reversibility of mRNA expression for angiotensin II type $2\left(\mathrm{AT}_{2}\right)$ receptor and angiotensinogen was observed after the return to normoxic conditions for 2 and 3 weeks respectively when compared with that of their respective controls. Results from Western blot analysis further confirmed that the expression of $\mathrm{AT}_{1}$ receptor protein was also reversible after return to normoxic conditions for 4 weeks. In addition, the activation of ACE activity returned to its normal level in a time-dependent manner. These data indicate that the upregulation of a local pancreatic RAS affected by chronic hypoxia could be recoverable. The significance of its reversibility and adaptability following chronic hypoxia may be of physiological relevance to the pancreas.
\end{abstract}

Journal of Molecular Endocrinology (2003) 31, 563-571

\section{Introduction}

The classical concept of the renin-angiotensin system (RAS) has been considered a circulating hormonal system that plays a crucial role in the maintenance of blood pressure. The physiologically active component of this system is angiotensin II. It originates from hepatic angiotensinogen acted upon by sequential processing of renin and angiotensin-converting enzyme (ACE), which are derived from the kidney and lung respectively (Menard et al. 1993). The action of angiotensin II is mediated through its interaction with two pharmacologically defined receptors, namely angiotensin II type 1 and type $2\left(\mathrm{AT}_{1}\right.$ and $\left.\mathrm{AT}_{2}\right)$ receptors $(\mathrm{De}$ Gasparo et al. 2000).
Recently, the expression of RAS components was detected in multiple tissues and organs (Vinson et al. 1998, De Mello \& Danser 2000, Leung 2002). Among these tissues and organs, our previous studies have demonstrated the existence of several key RAS components in the pancreas of rodents (Leung et al. 1997, 1999). Such a local pancreatic RAS plays a pivotal role in regulating the endocrine and exocrine functions of the pancreas (see review by Leung \& Chappell 2003). Interestingly, the components of this local system are responsive to various physiological and pathophysiological stimuli (see review by Leung \& Carlsson 2001). For example, our recent studies showed that the pancreatic RAS components were upregulated by experimental models of acute 
Table 1 Sequences of primers used and length of PCR products amplified

\begin{tabular}{|c|c|c|c|}
\hline & Primer & Sequence & $\begin{array}{l}\text { GeneBank no } \\
\text { /PCR product (bp) }\end{array}$ \\
\hline $\begin{array}{l}\text { Gene } \\
\text { Ao }\end{array}$ & $\begin{array}{l}\text { Sense } \\
\text { Antisense } \\
\text { Ao-IR }\end{array}$ & $\begin{array}{l}\text { 5'TTCAGGCCAAGACCTCCC3' } \\
\text { 5'CCAGCCGGGAGGTGCAGT3' } \\
\text { 5'CCAGCCGGGAGGTGCAGTAGAGACCAGGGTGCCAAAG3' }\end{array}$ & $\begin{array}{l}\text { NM_134432 } \\
\text { Native: } 309 \\
\text { Competitor: } 236\end{array}$ \\
\hline $\mathrm{AT}_{1}$ & $\begin{array}{l}\text { Sense } \\
\text { Antisense } \\
\mathrm{AT}_{1}-\mathrm{IR}\end{array}$ & $\begin{array}{l}\text { 5'GCCTGCAAGTGAAGTGATTT3' } \\
\text { 5'TTTAACAGTGGCTTTGCTCC3' } \\
\text { 5'TTTAACAGTGGCTTTGCTCCTGAGTGCTTTCTCTGC3' }\end{array}$ & $\begin{array}{l}\text { X64052 } \\
\text { Native: } 204 \\
\text { Competitor: } 148\end{array}$ \\
\hline $\mathrm{AT}_{2}$ & $\begin{array}{l}\text { Sense } \\
\text { Antisense } \\
\mathrm{AT}_{2}-\mathrm{IR}\end{array}$ & $\begin{array}{l}\text { 5'TCTGGCTGTGGCTGACTT3' } \\
\text { 5'CAAGACTTGGTCACGGGT3' } \\
\text { 5'CAAGACTTGGTCACGGGTCAATCCCAGCAGACCACT3' }\end{array}$ & $\begin{array}{l}\text { X62295 } \\
\text { Native: } 511 \\
\text { Competitor: } 398\end{array}$ \\
\hline
\end{tabular}

Ao, angiotensinogen; $\mathrm{AT}_{1}$, angiotensin II type 1 receptor; $\mathrm{AT}_{2}$, angiotensin II type 2 receptor; IR, internal reverse primer; IF, internal forward primer.

pancreatitis and chronic hypoxia (Chan et al. 2000, Leung et al. 2000, Ip et al. 2003). The activation of RAS components by chronic hypoxia may represent either a pathological change or a safeguard mechanism of the biological systems in order to adapt to these changes (Ip et al. 2002). The main aim of the present study was designed to elucidate the nature of RAS activation in the pancreas. In this respect, the most typical characteristic of adaptation is the reversibility of its biological systems. Accordingly, we hypothesized that the upregulation of a local pancreatic RAS and its adaptability under chronic hypoxic stress should be of physiological relevance to the pancreas. The present study, therefore, aimed to examine the reversibility of some major components of a pancreatic RAS following chronic hypoxia. After one month of hypoxic exposure, rats were returned to normoxic conditions for a varying period of time and the reversibility of the major RAS components was examined in the pancreas.

\section{Materials and methods}

\section{Chronic hypoxia rat model and reversibility study}

For the exposure of rats to chronic hypoxia, Sprague-Dawley rats aged 28 days were raised inside an acrylic chamber filled with $10 \% \pm 0.5$ oxygen for isobaric hypoxia for 4 weeks, as described previously in our laboratory (Chan et al.
2000, Ip et al. 2002). After 4 weeks of hypoxia, rats were returned to normoxic conditions for a varying period of time, i.e. 1, 2, 3 and 4 weeks. The degree of recovery in the altered expression for each of the RAS components was examined accordingly. For controls, time- and age-matched rats were kept in the same housing and allowed to breathe room air. Ethical approval of the animal model was obtained from the Animal Experimentation Ethics Committee of the Chinese University of Hong Kong.

\section{Preparation of native and competitor template}

The strategy and procedure used for the construction of plasmids containing native and competitor products for angiotensinogen, $\mathrm{AT}_{1}$, and $\mathrm{AT}_{2}$ were similar to previously described methods (Tsai et al. 2001, 2002, Wu et al. 2002). Briefly, specific primer pairs were designed to amplify a fragment of DNA from mRNA transcript, and their brief details are shown in Table 1. These DNA fragments were cloned into PCR cloning vectors (TA cloning vector, Invitrogene, Carlsbad, CA, USA) and positive clones were identified. The internal primer was paired with the upstream primer to amplify a shorter fragment that also contains the downstream primer sequences (angiotensinogen and $\mathrm{AT}_{2}$ ) or vice versa $\left(\mathrm{AT}_{1}\right)$. The amplified fragment was again cloned into a PCR cloning vector and a positive clone was identified. This clone served as the competitor plasmid for angiotensinogen, $\mathrm{AT}_{1}$, and 
$\mathrm{AT}_{2}$ respectively. All amplified DNA fragments were sequenced by an ABI Prism terminator cycle sequencing kit (Perkin Elmer, Foster City, CA, USA) according to the manufacturer's protocol for verification. Plasmids containing native or competitor DNA were linearized by proper restriction enzymes and transcribed in vitro using T7 RNA polymerase (Promega, Madison, WI, USA). The transcribed RNAs were precipitated twice using sodium acetate $(0.3 \mathrm{M}, \mathrm{pH} 4.2)$ and $100 \%$ ethanol after DNase treatment and phenol-chloroform extraction. The concentrations of RNAs were quantified by OD 260 absorbance, aliquoted, and stored at $-80^{\circ} \mathrm{C}$. Each RNA aliquot was used only once to reduce variation due to potential degradation of RNA after freezing and thawing.

\section{Standard curve-quantitative competitive-RT-PCR}

The detailed procedure of standard curvequantitative competitive-RT-PCR was described previously (Tsai \& Wiltbank 1996). In brief, a constant amount of competitor RNA (3.2 attomoles) was added into the reverse transcription master mix $(50 \mathrm{mM}$ Tris-HCl, $75 \mathrm{mM} \mathrm{KGl,} 3 \mathrm{mM}$ $\mathrm{MgCl}_{2}, \mathrm{pH} 8 \cdot 3,10 \mathrm{mM}$ dithiothreitol, $100 \mathrm{pmol}$ random primer, $4 \mathrm{mM}$ dNTPs and $50 \mathrm{U}$ SuperScriptII RNase H-reverse transcriptase). This mix was then dispensed into $0.2 \mathrm{ml}$ thin wall PGR tubes, and serially diluted native RNA $(25 \cdot 6-0 \cdot 4$ attomoles) in $2 \mu \mathrm{l}$ diethyl pyrocarbonate-treated water or $2 \mu$ unknown mRNA samples were added individually to each tube. The reverse transcription was performed at $42{ }^{\circ} \mathrm{C}$ for $60 \mathrm{~min}$ followed by incubation at $95^{\circ} \mathrm{C}$ for $10 \mathrm{~min}$, and quick chilled to $4{ }^{\circ} \mathrm{C}$ in a programmable thermocycler (MJ Research PTC-200). Five microliters RT products were added to $15 \mu \mathrm{l} \mathrm{PCR} \mathrm{mix} \mathrm{(final} \mathrm{concentration:}$ $10 \mathrm{mM}$ Tris- $\mathrm{HCl}\left(\mathrm{pH} 9.0\right.$ at $\left.25^{\circ} \mathrm{C}\right), 1.5 \mathrm{mM}$ $\mathrm{MgCl}_{2}, 50 \mathrm{mM} \mathrm{KCl}, 0 \cdot 1 \%$ Triton X-100, 0.2 mM dNTPs, $0.5 \mathrm{U}$ Taq polymerase, and $0.4 \mu \mathrm{M}$ of primers). This was subjected to 30 cycles of amplification $\left(30 \mathrm{~s}\right.$ denaturation at $95^{\circ} \mathrm{C}, 30 \mathrm{~s}$ annealing at $57^{\circ} \mathrm{C}$, and $30 \mathrm{~s}$ elongation at $72{ }^{\circ} \mathrm{C}$ ) followed by final elongation at $72{ }^{\circ} \mathrm{C}$ for $5 \mathrm{~min}$. Ten microliters PCR products were directly separated on a $5 \%$ acrylamide gel with $1 \times \mathrm{TBE}$ buffer $(0.09 \mathrm{M}$ Tris, $0.09 \mathrm{M}$ boric acid, 0.001 M EDTA, pH 8.0) at $110 \mathrm{~V}$ for $40 \mathrm{~min}$ using a
Mini-protein II electrophoresis system (BioRad, Richmond, CA, USA). The gel was then stained with ethidium bromide and placed on a UV illuminator equipped with a camera connected to a computer. The gel image was analyzed using an image analyzer (Molecular Dynamics Image Quant, Sunnyvale, CA, USA). In each lane of the gel, the intensity of the native and competitor bands was quantified and the ratio of this intensity was calculated. The logarithmic ratio of native to competitor product was plotted against the logarithmic initial amounts of native product to produce the standard curve (see Figs 1, 3, and 5). Concentrations of specific mRNA transcripts in samples were calculated by comparison with the standard curve as previously described (Tsai \& Wiltbank 1996).

\section{Western blot analysis}

The procedures for immunoblotting of $\mathrm{AT}_{1}$ receptor were reported previously (Leung et al. 2001). Briefly, pancreatic tissues from the control and experimental rats were homogenized at $4{ }^{\circ} \mathrm{C}$ in water, 1:9 (wt/vol) containing $10 \mathrm{mM} \mathrm{EDTA}$ and $1 \mathrm{mM}$ phenylmethylsulfonyl fluoride. The resultant protein was determined (Bio-Rad Protein Assay, Bio-Rad Laboratories, Hercules, CA, USA) for sodium dodecyl sulfate-polyacrylamide gel electrophoresis. Proteins ( $5 \mu \mathrm{g} / \mathrm{lane})$ were subjected to electrophoresis on a $12 \%$ (vol/vol) polyacrylamide gel in SDS and the gel was then processed for electroblotting to a polyvinylidene difluoride membrane. The blotted membrane was saturated with 5\% (wt/vol) skimmed milk in PBS, $\mathrm{pH} 7 \cdot 4$ and $0 \cdot 1 \%$ (vol/vol) Tween 20 for $1 \mathrm{~h}$ at room temperature. The membrane was then incubated in $\mathrm{AT}_{1}$ receptor antibody (Santa Cruz Biotechnology Inc., Santa Cruz, CA, USA, 1/1000) overnight at $4{ }^{\circ} \mathrm{C}$ and peroxidase-labeled $\mathrm{IgG}$ serum $(1 / 500)$ for $1 \mathrm{~h}$ at room temperature. The positive band was revealed using an ECL detection kit (Amersham Biosciences, Uppsala, Sweden) and quantified with an image analyzer.

\section{Specific assay for ACE activity}

The method for the measurement of ACE activity in rat pancreas has been described in detail from our previous publication (Ip et al. 2003). Briefly, the protein fraction was isolated from 
(A)

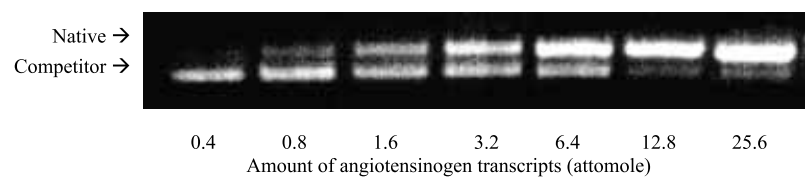

(B)

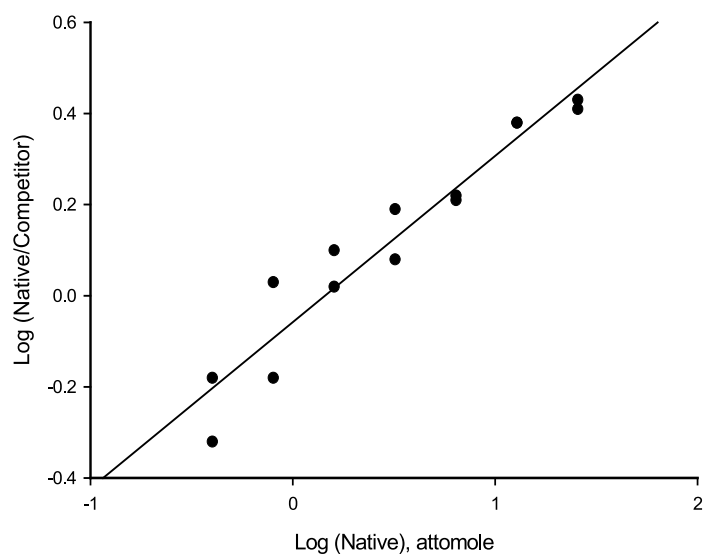

Figure 1 Quantification of angiotensinogen mRNA by quantitative competitive-RT-PCR. (A) Representative gel image of ethidium bromide-stained PCR products (0.4-25.6 attomoles) of native RNA co-amplified with 3.2 attomoles of competitor RNA. (B) Standard curve produced by analyzing the intensity of the bands shown in panel $A$. The log ratio of native to competitor product was plotted against the log amount of initial native RNA added to the RT-PCR.

pancreatic homogenate by the CytoBuster Protein Extraction Assay kit (Novagen, Madison, WI, USA) and incubated with $20 \mu \mathrm{M}$ fluorogenic substrate (2-amino-3-(7-methoxy-4-coumaryl) propanoic acid) at $37^{\circ} \mathrm{C}$ for $60 \mathrm{~min}$. The fluorescence of the supernatant was measured using an excitation wavelength at $328 \mathrm{~nm}$ and an emission wavelength at $392 \mathrm{~nm}$. ACE activity was calculated and expressed as $\mu \mathrm{mol} / \mathrm{min} / \mu \mathrm{g}$ protein.

\section{Data analysis}

Data were expressed as means \pm S.E.M. and analyzed by one-way ANOVA followed by Duncan's multiple range test in order to detect inter-group differences. Significant difference from the control was set at $P<0 \cdot 05$.

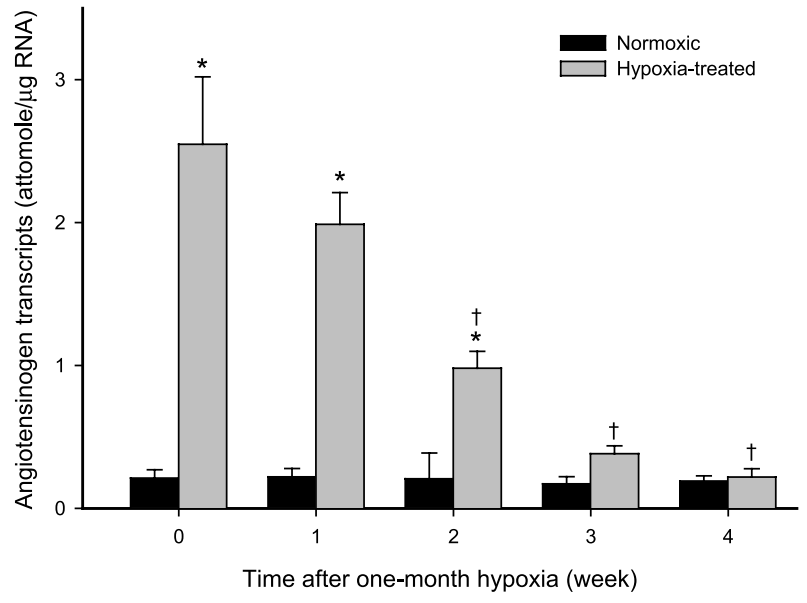

Figure 2 Time-dependent recovery of pancratic angiotensinogen mRNA from the effects of one month of hypoxia. Values given are means \pm S.E.M., $n=4$. *Significantly different from the normoxic control (0 week). ${ }^{\dagger}$ Significantly different from the hypoxiatreated control ( 0 week). The level of angiotensinogen mRNA (attomoles/ $\mu \mathrm{g}$ RNA) was plotted against the time (week) after one month of hypoxia

\section{Results}

\section{Expression and reversibility of angiotensinogen mRNA}

RT-PGR with internal RNA competitive standards provides a convenient way of measuring absolute amounts of mRNA transcripts. A standard curve was produced with serially diluted native angiotensinogen RNA (25.6 to 0.4 attomoles) and a constant amount (3.2 attomoles) of competitive RNA (Fig. 1). The amount of angiotensinogen mRNA in an unknown sample was then determined directly by comparison with the ratio of PCR products to the standard curve. This method has been shown to be sensitive, repeatable, and quantitative (Tsai \& Wiltbank 1996). By this method, the amount of angiotensinogen mRNA in rat pancreas was measured. The data showed that angiotensinogen mRNA was decreased time-dependently when the rats were returned to normoxic conditions for 1 to 4 weeks after a one-month hypoxic exposure. The expression of angiotensinogen mRNA completely recovered after 2 weeks (Fig. 2).

\section{Expression and reversibility of $\mathrm{AT}_{1}$ receptor mRNA}

A competitive RT-PGR standard curve was produced with different amounts of native $\mathrm{AT}_{1}$ 
(A)

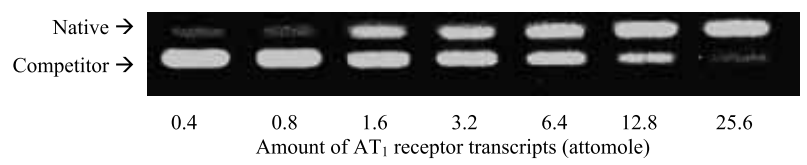

(B)

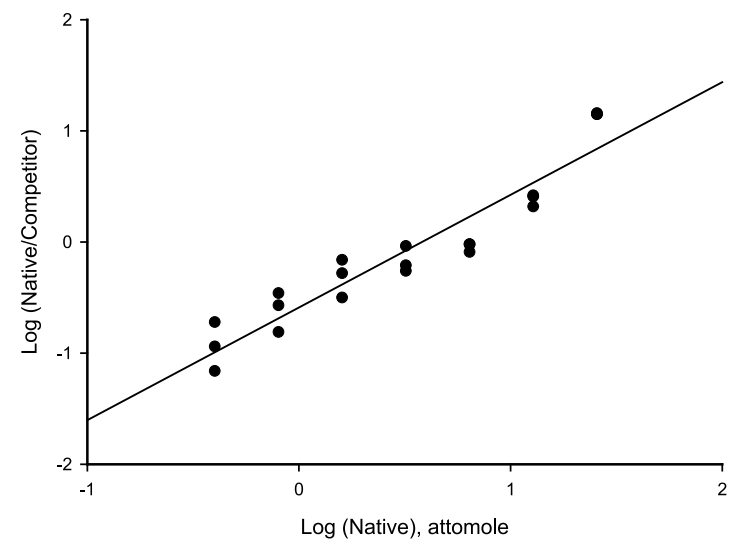

Figure 3 Quantification of $A T_{1}$ receptor mRNA by quantitative competitive-RT-PCR. (A) Representative gel image of ethidium bromide-stained PCR products (0.4-25.6 attomoles) of native RNA co-amplified with 3.2 attomoles of competitor RNA. (B) Standard curve produced by analyzing the intensity of the bands shown in panel $A$. The log ratio of native to competitor product was plotted against the log amount of initial native RNA added to the RT-PCR.

receptor RNA and a constant amount of competitive RNA (Fig. 3). $\mathrm{AT}_{1}$ receptor mRNA was decreased time-dependently when the rats were returned to normoxic conditions for 1 to 4 weeks. The recovery of angiotensinogen mRNA was faster than that of $\mathrm{AT}_{1}$ receptor $\mathrm{mRNA}$, which was restored to the level of the control after 3 weeks (Fig. 4).

\section{Expression and reversibility of $\mathrm{AT}_{2}$ receptor mRNA}

A competitive RT-PGR standard curve was produced with different amounts of native $\mathrm{AT}_{2}$ receptor RNA and a constant amount of competitive RNA (Fig. 5). After one month of hypoxic exposure, the increased level of $\mathrm{AT}_{2}$ receptor mRNA was reversibly regulated when the animals were returned to normoxic conditions. The

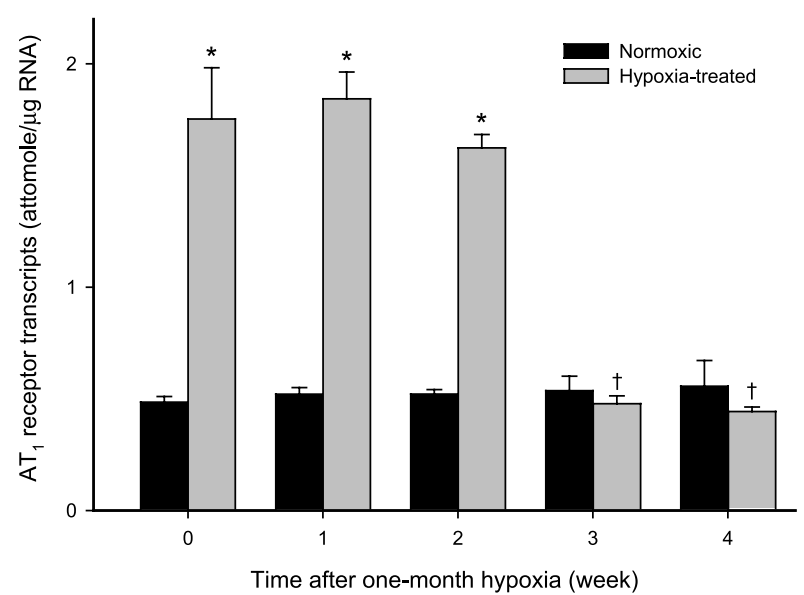

Figure 4 Time-dependent recovery of pancreatic $\mathrm{AT}_{1}$ receptor mRNA from the effects of one month of hypoxia. Values given are means \pm S.E.M., $n=4$. *Significantly different from the normoxic control (0 week). ${ }^{\dagger}$ Significantly different from the hypoxia-treated control ( 0 week). The level of $A T_{1}$ receptor mRNA (attomoles/ug RNA) was plotted against the time (week) after one month of hypoxia.

recovery of $\mathrm{AT}_{2}$ receptor mRNA was much faster than that of $\mathrm{AT}_{1}$ receptor and angiotensinogen mRNAs. Its level was completely recovered when the animals were returned to a normoxic environment for 2 weeks (Fig. 6).

\section{Expression and reversibility of $\mathrm{AT}_{1}$ receptor protein}

In parallel with the expression of $\mathrm{AT}_{1}$ receptor mRNA, the level of $\mathrm{AT}_{1}$ receptor protein was determined by Western blot analysis. A standard curve was produced with serial dilutions of $\mathrm{AT}_{1}$ receptor protein (Fig. 7). After one month of hypoxic exposure, there was a time lag in the recovery of $\mathrm{AT}_{1}$ receptor protein when compared with $\mathrm{AT}_{1}$ receptor mRNA (Fig. 4). $\mathrm{AT}_{1}$ receptor protein was not significantly changed when the rats were returned to normoxic conditions for the first 3 weeks. However, its expression level completely recovered after 4 weeks (Fig. 8).

\section{Reversibility of pancreatic ACE activity}

ACE activity was measured by a specific fluorometric assay. ACE activity in the rat pancreas was decreased time-dependently when the rats were returned to normoxic conditions for 1 to 4 weeks. 


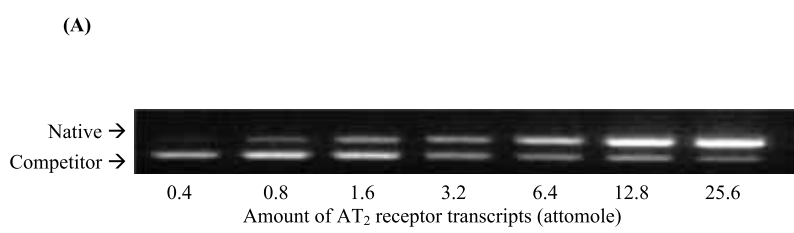

(B)

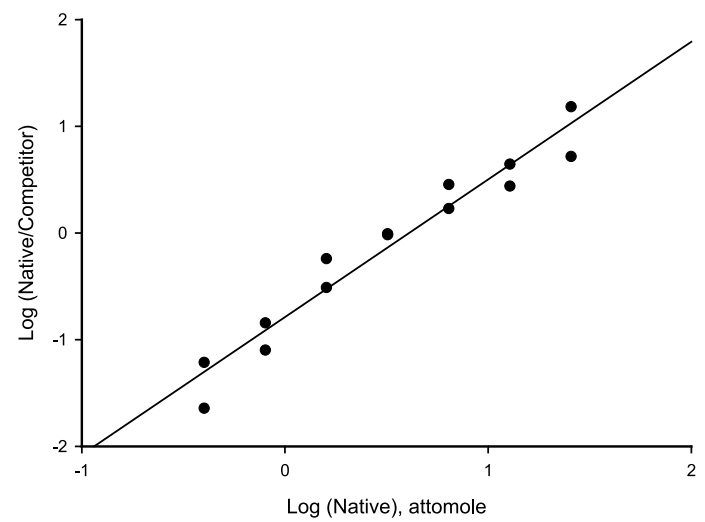

Figure 5 Quantification of $\mathrm{AT}_{2}$ receptor mRNA by quantitative competitive-RT-PCR. (A) Representative gel image of ethidium bromide-stained PCR products (0.4-25.6 attomoles) of native RNA co-amplified with 3.2 attomoles of competitor RNA. (B) Standard curve produced by analyzing the intensity of the bands shown in panel A. The log ratio of native to competitor product was plotted against the log amount of initial native RNA added to the RT-PCR.

The ACE activity was restored to the level of the control after returning to normoxic conditions for 3 weeks (Fig. 9).

\section{Discussion}

Hypoxia is a common stress that affects an organism's homeostasis. Although much information about the mechanisms of the cellular and biochemical responses to hypoxia have been provided, very little is known about the responses of the pancreas to chronic hypoxia. Our previous study showed that chronic hypoxia could upregulate the RAS components in the rat pancreas (Chan et al. 2000, Ip et al. 2003). The activation of pancreatic RAS components may represent a pathophysiological and a physiological phenomenon. A pathological condition is represented by a consistent upregulation of RAS components even when the subjects are returned to normoxic

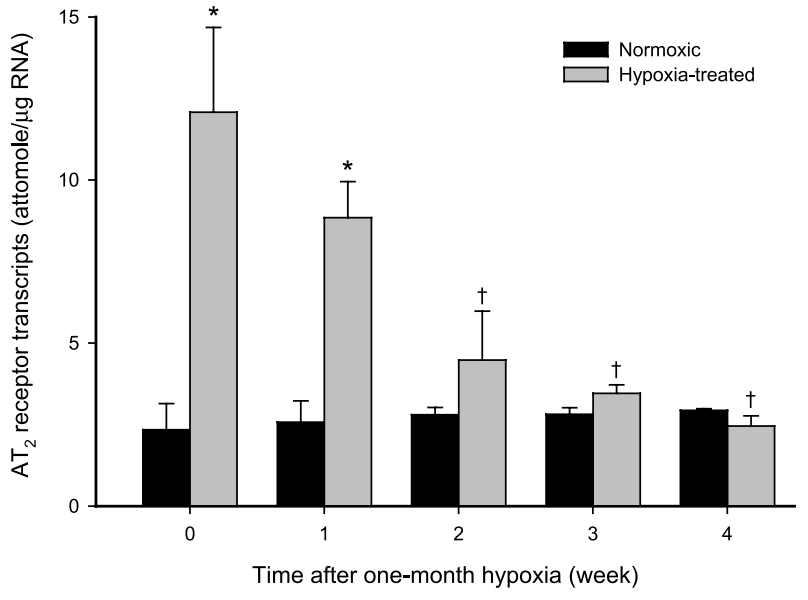

Figure 6 Time-dependent recovery of pancreatic $A T_{2}$ receptor mRNA from the effects of one month of hypoxia. Values given are means \pm S.E.M., $n=4$. *Significantly different from the normoxic control (0 week). ${ }^{\top}$ Significantly different from the hypoxia-treated control ( 0 week). The level of $A T_{1}$ receptor mRNA (attomoles/ug RNA) was plotted against the time (week) after one month of hypoxia.

conditions for a long time. In such a case, therapeutic intervention is required to avoid further deterioration of the biological system. It is well known that activation of the angiotensin II receptors is associated with hypertensive diseases (Berry et al. 2001, Wagenaar et al. 2002). On the other hand, a physiological condition is manifested with an adaptive response, in which the RAS components increase temporarily under adverse environmental conditions and recover when returned to normal conditions. The most typical characteristic of adaptation is its reversibility. The present study clearly demonstrated the reversibility of a pancreatic RAS in rats exposed to one month of hypoxia. Among the results, the time required for the recovery of the major pancreatic RAS components including mRNA of $\mathrm{AT}_{1}, \mathrm{AT}_{2}$ and angiotensinogen was $2-3$ weeks as shown in Figs 2, 4 and 6 . When compared with the two angiotensin II receptor subtypes, the recovery of $\mathrm{AT}_{2}$ receptor mRNA (Fig. 6) preceded that of $\mathrm{AT}_{1}$ receptor mRNA (Fig. 4). It was intriguing that there was a time lag in the recovery of $\mathrm{AT}_{1}$ receptor protein (Fig. 8) when compared with that of $\mathrm{AT}_{1}$ receptor mRNA. Nevertheless, all RAS components observed in the present study were completely reversible when the animals were returned to normoxic conditions for 4 weeks (Figs 2, 4, 6, 8, 9). 
(A)

$50 \mathrm{kDa} \rightarrow$

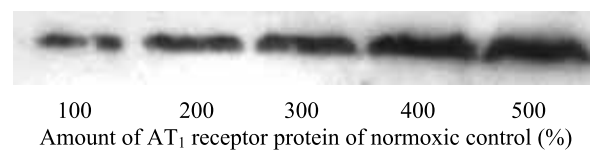

(B)

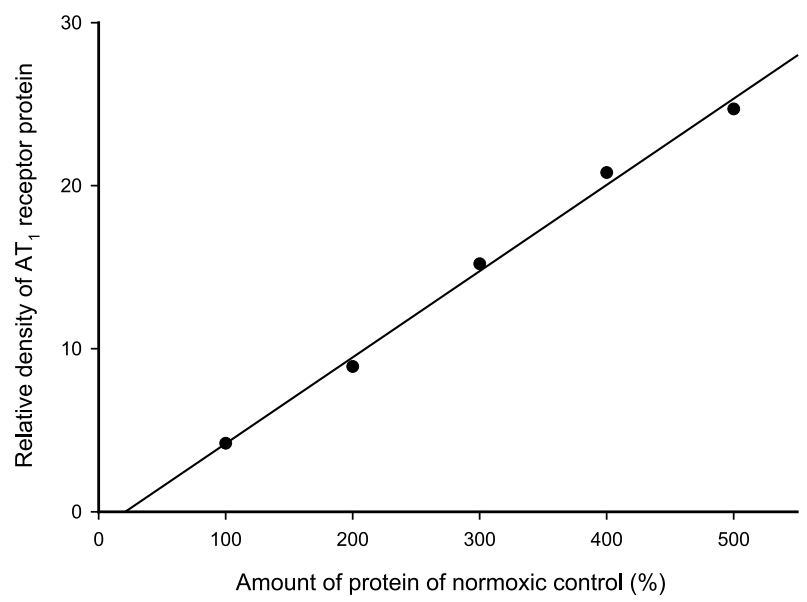

Figure 7 Quantification of $A T_{1}$ receptor protein by Western blot. (A) Representative gel image of Western analysis of $A T_{1}$ receptor protein. (B) Standard curve produced by analyzing the intensity of the bands shown in panel $A$.

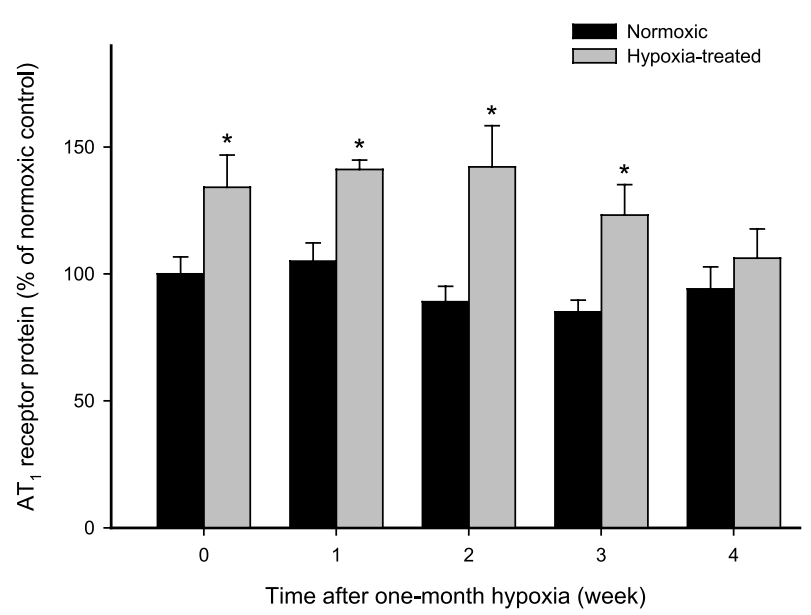

Figure 8 Time-dependent recovery of pancreatic $A T_{1}$ receptor protein from the effects of one month of hypoxia. Values given are means \pm S.E.M., $n=5$. *Significantly different from the control at the same time point. The level of $\mathrm{AT}_{1}$ receptor protein was plotted against the time (week) after one month of hypoxia.

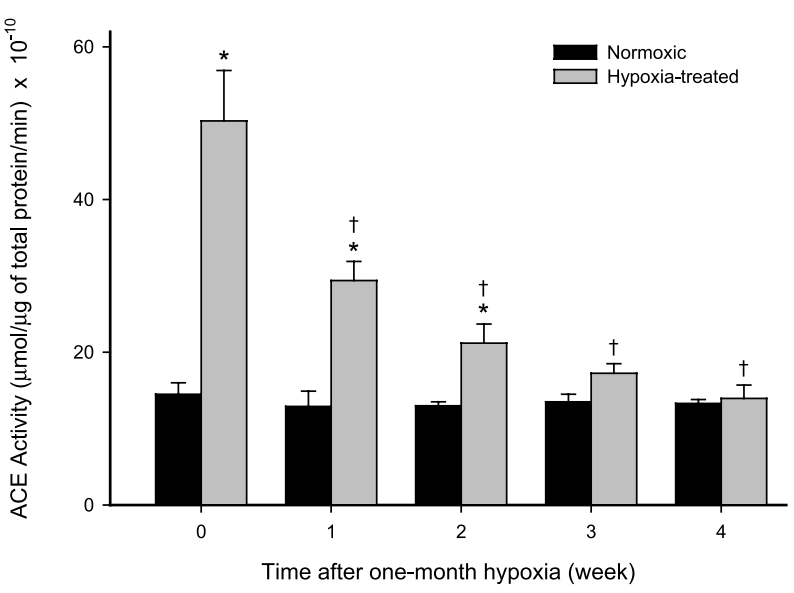

Figure 9 Time-dependent recovery of pancreatic ACE activity from the effects of one month of hypoxia. Values given are means \pm S.E.M., $n=5$. *Significantly different from the normoxic control (0 week). ${ }^{\dagger}$ Significantly different from the hypoxia-treated control ( 0 week). The activity of ACE ( $\mu \mathrm{mol} / \mu \mathrm{g}$ total protein $/ \mathrm{min}$ ) was plotted against the time (week) after one month of hypoxia.

The reversible regulation of pancreatic RAS by chronic hypoxia could play an important role in the physiological aspect of the pancreas. In fact, a recent finding showed the pulmonary expression and functional role of $\mathrm{AT}_{1}$ and $\mathrm{AT}_{2}$ receptors during hypoxic pulmonary hypertension development and their subsequent reversal upon return to normoxic conditions (Chassagne et al. 2000). Under hypoxic conditions, the RAS has been suggested to play a pivotal role in the preservation of blood supply to organs (Achard et al. 2001). In addition to its pressor function, angiotensin II can exert its effect through two time-dependent events. The RAS controls a fast opening of the reserve collateral circulation and a slow response of angiogenesis to acute hypoxia and chronic hypoxia respectively (Achard et al. 2001). In recent years, much attention has been focused on the role of the RAS in regulating angiogenesis and rarefaction. Angiotensin II has been suggested as a regulator of microvessel density acting through the mediation of $\mathrm{AT}_{1}$ and $\mathrm{AT}_{2}$ receptors (Greene \& Amaral 2002). It has been reported that the RAS stimulated the production of vascular endothelial growth factor (Chua et al. 1998, Lonchampt et al. 2001). A recent study demonstrated that the RAS promoted early angiogenesis by supporting inflammatory cell infiltration and angiogenic cytokine expression (Sasaki et al. 2002). However, other studies showed 
that the RAS inhibited angiogenesis (Celerier et al. 2002, Silvestre et al. 2002). This discrepancy could be due to the distinct distribution of $\mathrm{AT}_{1}$ and $\mathrm{AT}_{2}$ receptors in different organs. The RAS may stimulate angiogenesis in vital organs but may inhibit the process in organs with higher tolerance to hypoxia when there is a shortage of oxygen supply.

The upregulation of a local RAS by chronic hypoxia may result in other undesirable and pathological changes such as inflammation and stimulation of free radical formation. Many studies have shown that the RAS may enhance an inflammatory response through the production of inflammatory cytokines (Schieffer et al. 2000) and the recruitment of inflammatory cells (Alvarez \& Sanz 2001, Kintscher et al. 2001). Our recent study showed that experimental pancreatitis was associated with the activation of a local pancreatic RAS (Leung et al. 2000, Ip et al. 2003). Interestingly, administration of saralasin, a non-specific angiotensin II receptor antagonist of RAS, could be protective against the severity of acute pancreatitis, indicating that activation of a pancreatic RAS may play a role in pancreatic tissue injury (Tsang et al. 2003). Taken together, a pancreatic RAS may have a potential value in the manipulation of some pancreatic diseases (Leung 2003). In addition, many studies have shown that angiotensin II stimulated the formation of reactive oxygen species through the activation of $\mathrm{NAD}(\mathrm{P}) \mathrm{H}$ oxidase (Warnholtz et al. 1999, Wingler et al. 2001, Schieffer et al. 2000). Fortunately, the production of reactive oxygen species is limited under low oxygen tension. However, when the animals are returned to normoxic conditions, the production of oxygen radicals may be drastically enhanced. When the formation of reactive oxygen species exceeds the capacity of the antioxidant defence it results in oxidative damage to cellular molecules. The situation is similar to the well-known ischemia/ reperfusion injury in which xanthine oxidase, instead of $\mathrm{NAD}(\mathrm{P}) \mathrm{H}$ oxidase, is activated (AnayaPrado et al. 2002). Therefore, the reversible regulation of pancreatic RAS may represent a safeguard mechanism under the different insult of chronic hypoxia.

In conclusion, the present study clearly demonstrated the reversibility of upregulated pancreatic RAS due to chronic hypoxia. The reversible changes of a local pancreatic RAS imply a typical characteristic of an adaptive response and represent different aspects of physiological modification in the pancreas under different oxygen tension.

\section{Acknowledgements}

We are grateful for the financial support by the Competitive Earmarked Research Grant from the Research Grants Council of Hong Kong (Project No: CUHK 4116/01 M and CUHK 4074/00 M) and by the Chinese University of Hong Kong.

\section{References}

Achard J, Fournier A, Mazouz H, Caride VJ, Penar PL \& Fernandez LA 2001 Protection against ischemia: a physiological function of the renin-angiotensin system. Biochemical Pharmacology 62 261-271.

Alvarez A \& Sanz MJ 2001 Reactive oxygen species mediate angiotensin II-induced leukocyte-endothelial cell interactions in vivo. Fournal of Leukocyte Biology 70 199-206.

Anaya-Prado R, Toledo-Pereyra LH, Lentsch AB \& Ward PA 2002 Ischemia/reperfusion injury. Journal of Surgical Research 105 $248-258$

Berry C, Touyz R, Dominiczak AF, Webb RC \& Johns DG 2001 Angiotensin receptors: signaling, vascular pathophysiology, and interactions with ceramide. American foumal of Physiology $\mathbf{2 8 1}$ 2337-2365.

Celerier J, Cruz A, Lamande N, Gasc JM \& Corvol P 2002 Angiotensinogen and its cleaved derivatives inhibit angiogenesis. Hypertension $39224-228$.

Chan WP, Fung ML, Nobiling R \& Leung PS 2000 Activation of local renin-angiotensin system by chronic hypoxia in rat pancreas. Molecular and Cellular Endocrinology 160 107-114.

Chassagne C, Eddahibi S, Adamy C, Rideau D, Marotte F, Adnot S, Samuel J \& Teiger E 2000 Modulation of angiotensin II receptor expression during development and regression of hypoxic pulmonary hypertension. American Joumal of Respiratory Cell and Molecular Biology 22 323-332.

Chua CC, Hamdy RC \& Chua BH 1998 Upregulation of vascular endothelial growth factor by angiotensin II in rat heart endothelial cells. Biochimica et Biophysica Acta 1401 187-194.

De Gasparo M, Catt KJ, Inagami T, Wright JW \& Unger TH 2000 The angiotensin II receptors. Pharmacological Reviews 52 415-472.

De Mello WC \& Danser AH 2000 Angiotensin II and the heart: on the intracrine renin-angiotensin system. Hypertension 35 1183-1188.

Greene SO \& Amaral SL 2002 Microvascular angiogenesis and the renin-angiotensin system. Current Hypertension Reports 4 56-62.

Ip SP, Chan YW \& Leung PS 2002 Effects of chronic hypoxia on the circulating and pancreatic renin-angiotensin system. Pancreas 25 296-300.

Ip SP, Kwan PC, Williams CH, Pang S, Hooper NM \& Leung PS 2003 Changes of angiotensin-converting enzyme activity in the pancreas of chronic hypoxia and acute pancreatitis. International Fournal of Biochemistry and Cell Biology $35944-954$.

Kintscher U, Wakino S, Kim S, Fleck E, Hsueh WA \& Law RE 2001 Angiotensin II induces migration and Pyk2/paxillin phosphorylation of human monocytes. Hypertension 37 587-593. 
Leung PS 2002 Intrinsic angiotensin-generating system: its tissue-specific functions and clinical implications. Panminerva Medica 44 93-97.

Leung PS 2003 Pancreatic renin-angiotensin system: a novel target for the potential treatment of pancreatic disease. FOP Fournal of Pancreas 4 89-91.

Leung PS \& Carlsson PO 2001 Tissue renin-angiotensin system: its expression, localization, regulation and potential role in the pancreas. Fournal of Molecular Endocrinology 26 155-164.

Leung PS \& Chappell MC 2003 A local pancreatic renin-angiotensin system: endocrine and exocrine roles. International Fournal of Biochemistry and Cell Biology 35 838-846.

Leung PS, Chan HC, Fu LX \& Wong PY 1997 Localization of angiotensin II receptor subtypes $\mathrm{AT}_{1}$ and $\mathrm{AT}_{2}$ in the pancreas of rodents. Fournal of Endocrinology 153 269-274.

Leung PS, Chan WP, Wong TP \& Sernia C 1999 Expression and localization of renin-angiotensin system in the rat pancreas. Fournal of Endocrinology $\mathbf{1 6 0}$ 13-19.

Leung PS, Chan WP \& Nobiling R 2000 Regulated expression of pancreatic renin-angiotensin system in experimental pancreatitis. Molecular and Cellular Endocrinology 166 121-128.

Leung PS, Tsai SJ, Wallukat G, Leung TN \& Lau TK 2001 The upregulation of angiotensin II receptor AT1 in human preeclamptic placenta. Molecular and Cellular Endocrinology $\mathbf{1 8 4}$ 95-102.

Lonchampt M, Pennel L \& Duhault J 2001 Hyperoxia/normoxiadriven retinal angiogenesis in mice: a role for angiotensin II. Investigative Ophthalmology and Visual Science 42 429-432.

Menard J, Clauser E, Bouhnik J \& Corvol P 1993 Angiotensinogen: biochemical aspects. In The Renin-Angiotensin System, pp 8*1-8·10. Eds JIS Robertson \& MS Nichollas. London: Gower Medical Publishing.

Sasaki K, Murohara T, Ikeda H, Sugaya T, Shimada T, Shintani S \& Imaizumi T 2002 Evidence for the importance of angiotensin II type 1 receptor in ischemia-induced angiogenesis. Fournal of Clinical Investigation 109 603-611.

Schieffer B, Luchtefeld M, Braun S, Hilfiker-Kleiner D \& Drexler H 2000 Role of $\mathrm{NAD}(\mathrm{P}) \mathrm{H}$ oxidase in angiotensin II-induced JAK/STAT signaling and cytokine induction. Circulation Research 87 1195-1201.

Silvestre JS, Tamarat R, Senbonmatsu T, Icchiki T, Besnard S, Inagami T \& Levy BI 2002 Antiangiogenic effect of angiotensin II type 2 receptor in ischemia-induced angiogenesis in mice hindlimb. Circulation Research $901072-1079$.

Tsai SJ \& Wiltbank MC 1996 Quantification of mRNA using competitive RT-PCR with standard-curve methodology. Biotechniques 21 862-866.

Tsai SJ, Wu MC, Lin CC, Sun HS \& Chen HM 2001 Regulation of steroidogenic acute regulatory protein expression and progesterone production in endometriotic stromal cells. Fournal of Clinical Endocrinology and Metabolism 86 5765-5773.

Tsai SJ, Wu MH, Chen SM, Chuang PC \& Wing LY 2002 Fibroblast growth factor-9 is an endometrial stromal growth factor. Endocrinology 143 2715-2721.

Tsang SW, Ip SP, Wong TP, Che CT \& Leung PS 2003 Differential effects of saralasin and ramiprilat, the inhibitors of renin-angiotensin system, on cerulein-induced acute pancreatitis. Regulatory Peptides 111 47-53.

Vinson GP, Teja R, Ho MM, Hinson JP \& Puddefoot JR 1998 The role of the tissue renin-angiotensin system in the response of the rat adrenal to exogenous angiotensin II. Fournal of Endocrinology 158 153-159.

Wagenaar LJ, Voors AA, Buikema H \& van Gilst WH 2002 Angiotensin receptors in the cardiovascular system. Canadian Fournal of Cardiology 18 1331-1339.

Warnholtz A, Nickenig G, Schulz E, Griendling KK, Harrison DG, Meinertz T \& Munzel T 1999 Increased NADH-oxidasemediated superoxide production in the early stages of atherosclerosis: evidence for involvement of the renin-angiotensin system. Circulation 99 2027-2033.

Wingler K, Wunsch S, Kreutz R, Rothermund L \& Schmidt HH 2001 Upregulation of the vascular $\mathrm{NAD}(\mathrm{P}) \mathrm{H}$-oxidase isoforms Nox 1 and Nox 4 by the renin-angiotensin system in vitro and in vivo. Free Radical Biology and Medicine 31 1456-1464.

Wu MH, Chung PC, Chen HM, Lin CG \& Tsai SJ 2002 Increased leptin expression in endometriosis cells is associated with endometrial stromal cell proliferation and leptin gene-upregulation. Molecular Human Reproduction 8 456-464.

Received 11 July 2003 Accepted 11 August 2003 